\title{
ルイス酸一共触媒系加硫の早期加硫 防止法に関する研究
}

(昭和37年12月26日 受理)

\begin{tabular}{|c|c|c|c|c|c|c|}
\hline 古 川 & 淳 & 二* $^{*}$ & 山 & $T$ & 晋 & $\equiv^{*}$ \\
\hline 下 & 秀 & $夫^{* *}$ & 岡 & & 昭 & $-*$ \\
\hline
\end{tabular}

要 旨 1オン加硫は一般にスコーチ性加大である，との防止法として有機アミン類のスコーチ防止勄果を

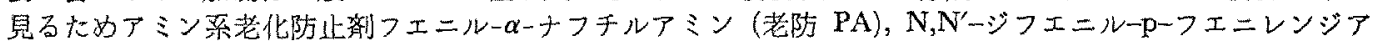

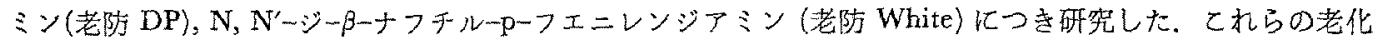
防汅剂の中を゙は老防 DP のスコーチ防止性が比较的大であったが，一般にアミン類は加硫速度を減じ，加 琉ゴムの物理的性質家但下させた。

またルイス酸の代りにトリベンジル錫クロライドを用いて加硫を行っだトリベンジル錫クロライドので とき有機金属八ロゲン化物はゴムへの混合溶解性が有効でありスコー手性委少いが，加硫ゴムの物理的性質 は良好で恬なかった。

\section{1. 緒言}

有機了ミン類のうち，2級及び 3 級アミン類はルイス

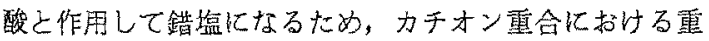

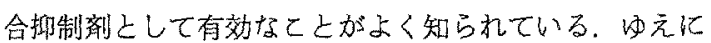

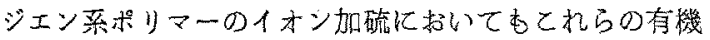
アミン類はスコーチ抑制剂として作用し，高温加熟によ り錯塩は分離し，加硫触媒として作用することが期待さ れるため，有機アミン類ししてアミン系老化防止剂を用 いて SBR のイオン加硫に叔けるスコー千抑制效果を検 詩した。

またイオン加硫のルイス酸としては $\mathrm{SnCl}_{2} \cdot 2 \mathrm{H}_{2} \mathrm{O}$ が 有效かつ安定である加拱機ハロゲン化物であるためゴム

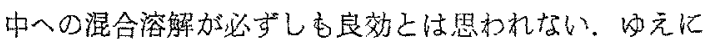
$\mathrm{SnCl}_{2} \cdot 2 \mathrm{H}_{2} \mathrm{O}$ の代りに有機錫ハロゲン化物莸使雨すれ ばゴムへの混合溶解が良荍となり，少星の使用で加硫効

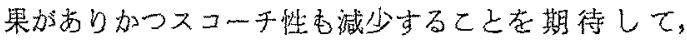
SBR について検討した.

\section{2. アミン系早期加硫防止剂}

\section{1 老化防止刘のスコ一チ抑制效果及び加硫ゴム の性質}

表 1 に示すどとくフエニルー

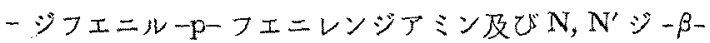
ナフチル - p-フエニレンジアミンの SBR のイホン加硫 スコーチ抑制效果を比較した，加硫速度の低下は $\mathrm{N}, \mathrm{N}^{\prime}$

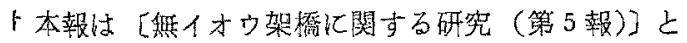
する。

*宗都大学工学部 合成化学科

***真洋ゴム工業株式会社 中央研究所
表1SBRのイォン加硫飞拉りるアミン系 老化防止剂の影響

\begin{tabular}{|c|c|c|c|c|c|}
\hline 配合 & Jo 1 & No 2 & No 3 & No 4 & No 5 \\
\hline SBR 1500 & 100 & 100 & 100 & 100 & 100 \\
\hline Philblack $-\mathrm{O}$ & 40 & 40 & 40 & 40 & 40 \\
\hline Circosol $2 X H$ & 8 & 8 & 8 & 8 & 8 \\
\hline 重 鉛 龩 & 4 & 一 & - & - & - \\
\hline ステアリン酸 & 2.5 & - & - & - & - \\
\hline $1+x^{2}$ & 2 & - & - & - & - \\
\hline 促進剂 CZ & 1.25 & $5-$ & - & - & - \\
\hline ベンゾトリクロライト & 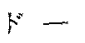 & 4 & 4 & 4 & 4 \\
\hline $\mathrm{SnCl} \mathrm{Cl}_{2} 2 \mathrm{H}_{2} \mathrm{O}$ & - & 4.6 & 4.6 & 4.6 & 4.6 \\
\hline 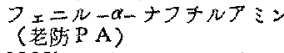 & 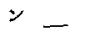 & - & 0.9 & - & - \\
\hline 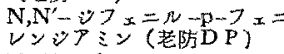 & $=-$ & - & - & 0.53 & $3-$ \\
\hline 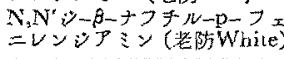 & e) & - & - & - & 0.74 \\
\hline
\end{tabular}

ムーニースコーチ[測定温度 $\left.250^{\circ} \mathrm{F}\right]$

10 点上舅 56 分55秒 2 分43秒 3 分 05 秒 5 分56秒 2 分47秒 20 点上景 62 分25秒 3 分 24 秒 4 行12秒 - - 3 分25秒 加硫時間
(分) 切䍘時伸び率 (96) 20492669756706719 $\left\{\begin{array}{llllll}40 & 350 & 619 & 717 & 644 & 625\end{array}\right.$ $\begin{array}{llllll}60 & 367 & 563 & 631 & 544 & 600\end{array}$

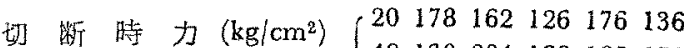
$\begin{array}{llllll}40 & 130 & 204 & 180 & 185 & 170\end{array}$ $\begin{array}{llllll}60 & 171 & 218 & 207 & 217 & 222\end{array}$ 硬 さ $シ ョ \rightarrow\left\{\begin{array}{llllll}20 & 63 & 63 & 60 & 56 & 54 \\ 40 & 62 & 58 & 56 & 60 & 59 \\ 60 & 64 & 62 & 60 & 62 & 61\end{array}\right.$

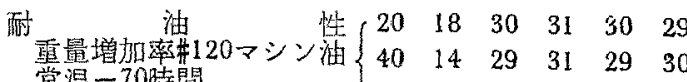
常温一70時間 $\quad\left\{\begin{array}{llllll}60 & 17 & 25 & 27 & 25 & 26\end{array}\right.$ 
シフエニルーp-フエニレンジアミンが大であり, $\mathrm{N}, \mathrm{N}^{\prime}-$ ジナフチルーP-フエニレンジアミンは全く影響しない.

またアミン類の配合はイオン加硫ゴムのモシュラス，切 断時力を低下し，切断時伸び摔を大とする倾间があるが

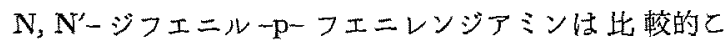
のような寒影響は少い上うである。しかしモールドの分 解ゴムによる污れはアミン類の配合により增加するよう である。

加硫ゴムの配合および物理的性算に関しては表 1 ，图 1 亿示す.

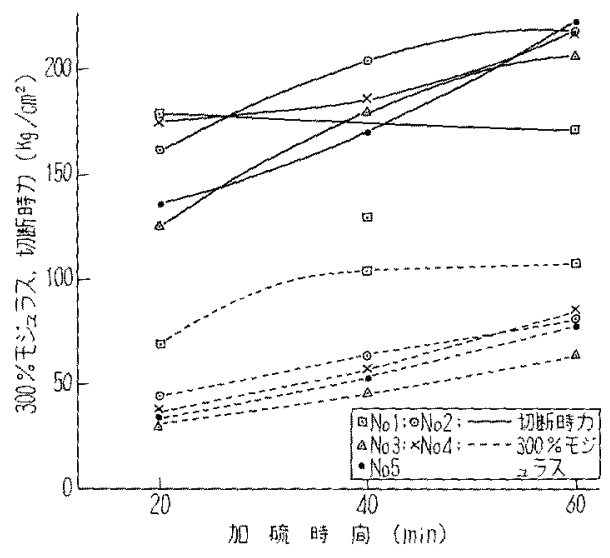

困 I 各種アミン類と切断㭙力，モジラ スの関係

2.2 SBR-流動塩化パラフィン系イオン加硫にお

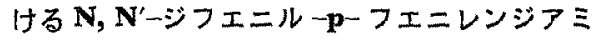
ンの影繷

第4報で報告したごよく反応性軟化剂として流動塩化

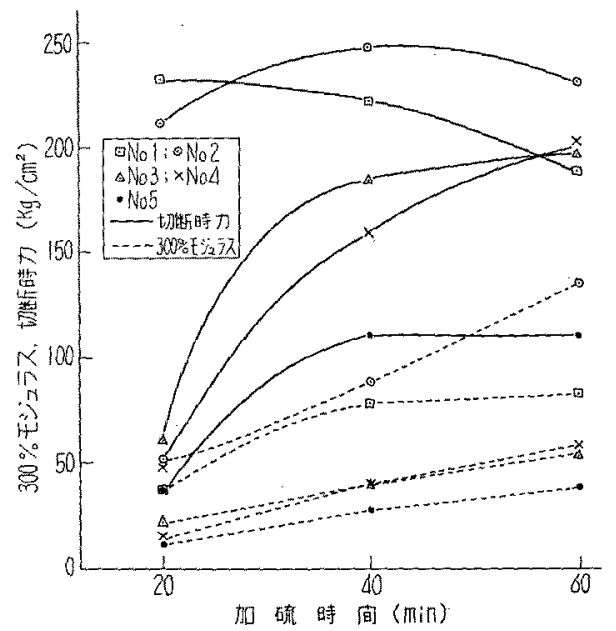

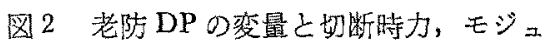
ラスの䦛係

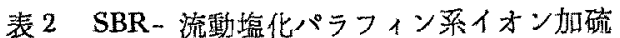
そ抬ける $\mathrm{N}, \mathrm{N}^{\prime}$ ージフエニルーp-フエニ レンジアミンの影響

\begin{tabular}{|c|c|c|c|c|c|}
\hline 配 & No 1 & No 2 & No 3 & No 4 & No 5 \\
\hline SBR 1502 & 100 & 100 & 100 & 100 & 100 \\
\hline $\mathrm{EPC}$ ブラック & 40 & 40 & 40 & 40 & 40 \\
\hline 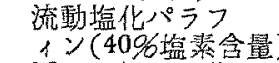 & & 8 & 8 & 8 & 8 \\
\hline 重鉛 華 & 4 & - & - & - & - \\
\hline ステアリン䠗 & 2.5 & - & - & - & - \\
\hline イオ ウ & 2 & - & - & - & - \\
\hline 促進剂 CZ & 1.25 & - & - & - & - \\
\hline 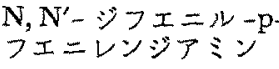 & $\mathrm{p}-1$ & - & 0.52 & 1.04 & 1.56 \\
\hline ベンゾトリクロライ & $1 F-$ & 2 & 2 & 2 & 2 \\
\hline $\mathrm{SnCl}_{2} \mathrm{H}_{2} \mathrm{O}$ & - & 2.3 & 2.3 & 2.3 & 2.3 \\
\hline
\end{tabular}

$ム$ ムニースコーチ[测定温度 $250^{\circ} \mathrm{F}$ ]

10 点上开 60 分 23 秒 4分 30 秒 10 分16秒 10 分20秒 15 分 45 秒 20 点上是 68 分0秒 5 分20秒16分39秒18分43秒45分12秒

\begin{tabular}{|c|c|c|c|c|c|c|}
\hline 扣硫ゴム特性 & (硫时) & & & 硫鼬 & 思度 1 & $\left.150^{\circ} \mathrm{C}\right]$ \\
\hline $300 \%$ モジ $=$ ス $(\mathrm{kg} / \mathrm{cm})$ & 20 & 37 & 51 & 21 & 15 & 13 \\
\hline & 40 & 78 & 88 & 40 & $4 !$ & 28 \\
\hline & 60 & 83 & 135 & 56 & 49 & 39 \\
\hline 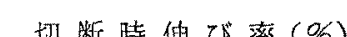 & 20 & 763 & 694 & 713 & 763 & 713 \\
\hline 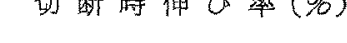 & 40 & 525 & 575 & 725 & 708 & 742 \\
\hline & 60 & 467 & 433 & 667 & 717 & 600 \\
\hline 切 此 時 力 $(\mathrm{kg} / \mathrm{cm})$ & 20 & 232 & 212 & 61 & 50 & 37 \\
\hline & 40 & 222 & 247 & 186 & 160 & 111 \\
\hline & 60 & 188 & 231 & 198 & 201 & 111 \\
\hline 士 (シアー) & 20 & 56 & 64 & 55 & 55 & 55 \\
\hline$\Leftrightarrow(2,3)-1$ & 40 & 62 & 65 & 60 & 64 & 63 \\
\hline & 60 & 64 & 70 & 63 & 64 & 64 \\
\hline 耐油性 & 20 & 32 & 24 & - & - & - \\
\hline 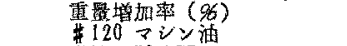 & 40 & 24 & 25 & 38 & 40 & 43 \\
\hline 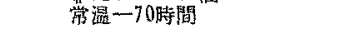 & 60 & 20 & 18 & 36 & 37 & 39 \\
\hline $\begin{array}{l}\text { ウイリアムス摩耗 } \\
\text { (cc/Phr) }\end{array}$ & 40 & 8 & 40 & 31 & 59 & 73 \\
\hline
\end{tabular}

パラフィンを用いてSBRのイオン加硫学行う場合, 触媒 一其触媒量㑞減少するととが可能であり，スコ一千性す

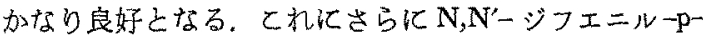
フエニレンジアンンを配合する場合の勃果を見る目的て 表 2 の配合で行った。

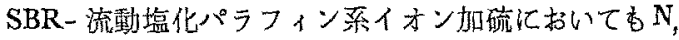
$\mathrm{N}^{\prime}$-ジフエニルーp-フエニレンジアミンの堌量估加硫速 度を減少し，No.4のどときは極度汇減少した，加硫速 度の娍少は種々の物理的性䝷を低下させ，酎油耐摩耗性 香不良となった。しのようにアミン類は少量であイオン

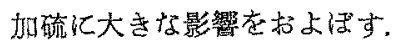

加硫ゴムの物理的性質を表 2 及び図 2 亿示す. 
3. トリベンジル錫クロライドーベンゾトリク ロライド系による SBR の加硫

3.1 トリベンジル錫クロライドの合成1) $\left(\mathrm{C}_{6} \mathrm{H}_{5} \mathrm{CH}_{2}\right)$ ${ }_{3} \mathrm{SnCl}$

塩化ベンジル40部, 錫粉39部, 水150部を強く攬拌しな がら 3 时間，泓点で反応させたのち吸引沃過し，アセ卜 ンから再結晶させた。収率84.5\%, 融点 $143.5 \sim 146^{\circ} \mathrm{C}$.

\subsection{SBR の加硫}

トリベンジル錫クロライドーベンゾトリクロライド系 によるSBR のイオン加硫化扔けるムーニースコーチは 触媒一共触媒量の変量之は整関係化活济同様の値を示し いずれるスコーチし難い。

加硫ゴムの物理的性复は触媒一共船媒量の多い屯の程 良好であるが通常のイオン加硫ゴムまた流イオ宁扣硫ゴ ムに此してか斿り劣った。

てのようにトリベンジル錫クロライドは SBR への混 合溶解が容易でスコーチし難いがイオン加硫的媒として の作用は $\mathrm{SnCl}_{2} \cdot 2 \mathrm{H}_{2} \mathrm{O}$ 上りか枋り少る。

表 3 及ご図 3 亿配合，ムーニースコーチ及び加硫ゴムの 物理的性犋などを示す。

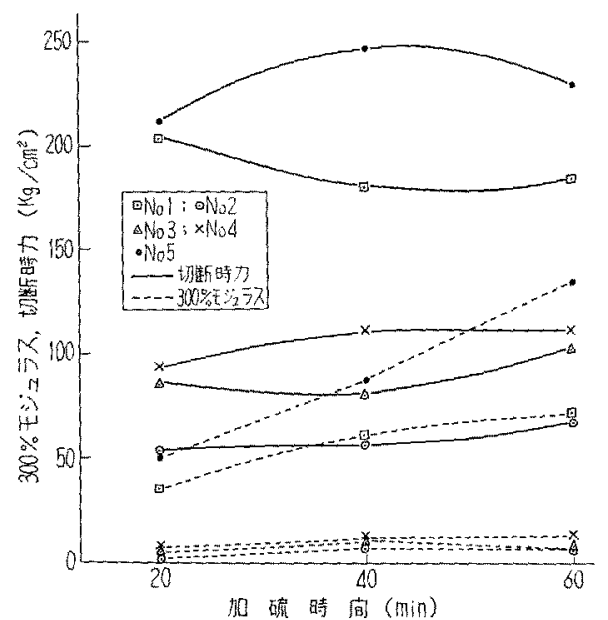

图 3 トリベンジル錫クロライドーベンジ トリクロライドの変量と切断時力, モジュラスの関係
表3トリベンジル錫クロライドーベンゾトリ クロライド采化よる SBRの扣硫

\begin{tabular}{|c|c|c|c|c|c|}
\hline 即 合 & No.1 & No.2 & No.3 N & No.4 & No.5 \\
\hline SBR 1502 & 100 & 100 & 100 & 100 & 100 \\
\hline $\mathrm{EPC}$ ブラック & 40 & 40 & 40 & 40 & 40 \\
\hline 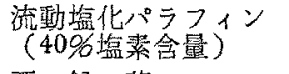 & 8 & 8 & 8 & 8 & 8 \\
\hline 瑟 鉊 弯 & 4 & - & - & - & - \\
\hline ステアリン酸 & 2.5 & 一 & - & - & - \\
\hline 1才ウ & 2 & - & - & - & - \\
\hline 促進剂 CZ & 1.25 & $5-$ & - & - & - \\
\hline ベンゾトりクロライト & - & 1 & 2 & 3 & 2 \\
\hline 15 & 一 & 2. 18 & 4.36 & 6.56 & $6-$ \\
\hline $\mathrm{SnCl}_{2} \cdot 2 \mathrm{H}_{2} \mathrm{O}$ & - & - & - & - & 2.3 \\
\hline
\end{tabular}

ムーニースコーチ [測定温度 $\left.250^{\circ} \mathrm{F}\right]$

10 点上显 68 分 53 秒 14 分50秒 13 分56秒 14分30秒 4分 30 秒 20 点上鼠 83 分16秒 24 分20秒 22 分 25 秒 23 分42秒 5 分 20 秒 加硫ゴム特性 加硫特間 〔加硫温度 $150^{\circ} \mathrm{C}$ ] $300 \%$ モジュラス $(\mathrm{kg} / \mathrm{cm})\left\{\begin{array}{rrrrrr}20 & 37 & 3 & 5 & 7 & 51 \\ 40 & 61 & 8 & 11 & 12 & 88 \\ 60 & 72 & 7 & 7 & 14 & 135\end{array}\right.$ 切断時伸ひ率 (\%) $20681 \quad 1213 \quad 1138 \quad 1013694$ $\begin{array}{llllll}40 & 525 & 950 & 875 & 938 & 575\end{array}$ $\begin{array}{llllll}60 & 463 & 988 & 975 & 825 & 433\end{array}$

切断時力 $\left(\mathrm{kg} / \mathrm{cm}^{2}\right)\left(\begin{array}{llllll}20 & 205 & 54 & 86 & 95 & 212\end{array}\right.$ $\left\{\begin{array}{lllllll}40 & 180 & 57 & 82 & 111 & 247\end{array}\right.$ $\begin{array}{llllll}60 & 185 & 67 & 103 & 112 & 231\end{array}$

硬

$$
\vec{c}(シ ョ ア \rightarrow)\left\{\begin{array}{llllll}
20 & 60 & 40 & 40 & 42 & 64 \\
40 & 63 & 42 & 42 & 43 & 65 \\
60 & 63 & 42 & 42 & 44 & 70
\end{array}\right.
$$
4. 結
論

ゴム苂化防止剂中 $\mathrm{N}, \mathrm{N}^{\prime}$-ジフエニルーP-フエニレン ジアミンはイオン加硫のスコーチ抑制効果加比較的大き いが，一般にアミン類の配合は加硫ゴムの物理的性質を 低下させ，酎油，酎摩耗性を不良已する。

有戥錫八ロゲン化物をルイス垔の代りに使用する特は ゴムへの混合溶解が容易ですりスコーチしがたいが，イ オン加硫触媒としての效果は $\mathrm{SnCl}_{2} \cdot 2 \mathrm{H}_{2} \mathrm{O}$ よりかなり多 るととが如った。

$$
\text { 文 献 }
$$

1) 穴户，趣川：日本特竍 205604 .

\section{SOME ATTEMPTS AT SCORCHPROOF IN NON-SULFUR VULCANIZA- ATION WITH BENZOTRICHLORIDE AND STANNOUS GHLORIDE.}

\section{NON-SULFUR VULCANIZATION OF SYNTHETIC RUBBERS: $v$.}

J. Furukawa, S. Yamashita (Department of Synthetic Chemistry, Kyoto University),

H. Matsushita, S. Oka (The Toyo Rubber Ind. Co., Ltd.) 
In the previous paper of this series (I-IV) it was described that metal chloride-halo-organic compound systems had constituted powerful non-sulfur vulcanizing systems. Curing rate of this type of vulcanizer being so high, it had been hard to obtain good mixes on the mill with much quantities of the above chlorides.

This paper deals with two attempts to dévelop the methods of scorch-proof in the curing systems. The results are as follows:

(1) Amine derivatives, i.e., phenyl- $\beta$-naphthylamine, $\mathrm{N}, \mathrm{N}^{\prime}$-diphenyl-p-phenylenediamine, showed a little effect on scorchproof but oil and abrasion resistance of the vulcanizates decreased.

(2) By use of benzyl tin trichloride, in place of stannous chloride, an improved dispersion in rubber matrix was attained and the rubber stocks had an excellent nature of slow vulcanization but the vulcanizate indicated poor physical properties.

\title{
ハードクレーのゴム補強譏構
}

\author{
（昭和38年 3 月 1 日 受理）
}

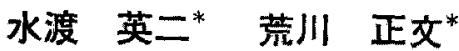

\begin{abstract}
要 旨 ハードクレーのゴムに対する袢强機構を主として赤外線吸收スペクトルの測定によって研究した。

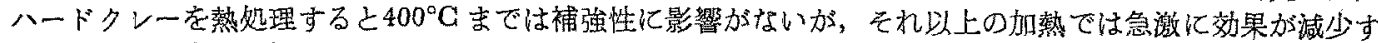
る、禈々の温度に熱炕理したハードクレーの粒度，ゴム中での分散度，此表湎積，結晶性，加熱減量などを 測定すると，見かけの粒子珍状，粒度，分散性などは熱好理によって变化しないが，結晶は400 $\mathrm{C}$ 以の加

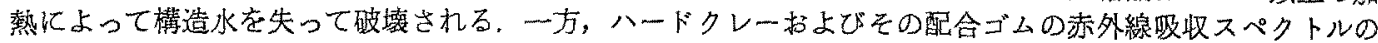

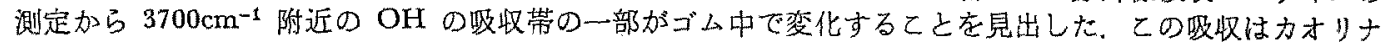

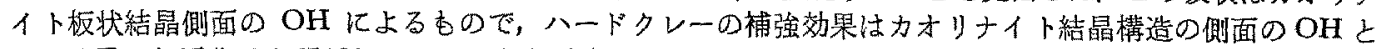
ゴム分子の相互作用が関係しているてとが示唆される。したがって加熱により結晶構造が破壊されると禣強 性が失われるのであろう。
\end{abstract}

\section{1. 緒言}

補強性充填郕の作用機構はまだ十分汇説明されていな い. しかし充填剂粒子表面の官能基とゴム分子間の吸着 または化学結合がゴム架橋棈造の形成に関与していると とは確実であ万う。たとえばカーボンブラックでは粒子 表面に存在するキノン基，ハイドロキノン基とゴム分子 の側鎖飽和基, 不飽和基之の結合が示唆されている。 またコロイダルシリカでは表面の遊離 $\mathrm{OH}$ 基とポリマ 一末端基との水素結合が予想され，さらにコロイダルシ リカ自身が遊離基受容体でポリマ一と反応する能力があ るという説少あある，著者らは合成ゴムに対して強い補 強性を有するカオリン䒺八ードクレーについて, クレー の熱処理に上る物性の変化之，そのゴム補強性に与天る 影響加ら作用機構を考察した。

†本報在〔赤外線吸收スペクトルによるゴム一充填剂 系の研究 (第 4 報尚) 了上する。

*京都大学 化学研究所

\section{2. 試料}

試料として用いたハードクレーは米国南カロライナ州 アイケン産のもので South Eastern 社製のものである.

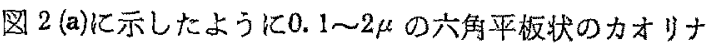
イト結晶粒子加らなっている。試料ゴムは SBR 1502で 配合比は表1に示した。

表 1

\begin{tabular}{lr}
\hline SBR 1502 & 100.0 \\
亜鉊華 & 5.0 \\
ステアリン酸 & 1.0 \\
イオウ & 2.0 \\
促進剤 DM & 1.5 \\
"M & 0.5 \\
シェチレングリコール & 3.0 \\
ハードクレー & 100.0 \\
\hline
\end{tabular}

$40 \mathrm{lb} / \mathrm{in}^{2}, 20$ 分プレス加硫 